\title{
Eğitimde Veli Katılımına Yönelik Çalışmaların İncelenmesi ${ }^{1}$
}

\section{Investigation Of Studies on Parent Involvement In Education}

\author{
Gözde YÜCETAŞ ARTAN² Recep KAHRAMANOĞLU³
}

\begin{tabular}{|c|c|}
\hline $\begin{array}{l}\text { Anahtar Kelimeler } \\
\text { Veli katılımı, } \\
\text { Okul aile iş } \\
\text { birliği, } \\
\text { Doküman } \\
\text { incelemesi. }\end{array}$ & 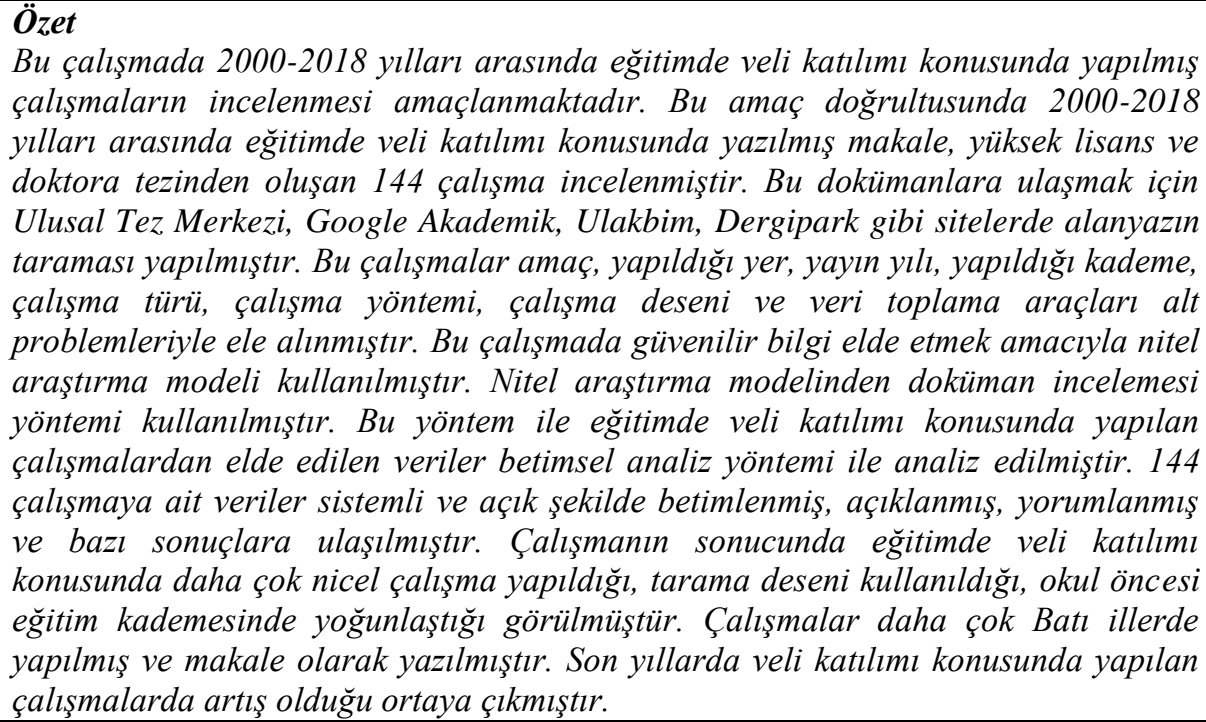 \\
\hline
\end{tabular}

\begin{abstract}
The aim of this study is to analyze the studies on parental involvement in education conducted between the years 2000-2018. In line with this purpose, 144 studies including articles, master's theses and doctoral theses applied on parental involvement between 2000-2018 were examined. To obtain these documents, a literature review on the related field was carried out with the help of websites such as National Thesis Center, Google Scholar, Ulakbim and Dergipark. These studies were examined in terms of some sub-problems such as aim, the place they were carried out, publication year, the level they were carried out, study type, research method, research design and data collection tools. The qualitative research design was used for this study to obtain reliable data. Literature review method which is a qualitative research design was used to analyze the data obtained from the studies on parental involvement in education via descriptive analysis method. The data from 144 studies were analyzed, explained and interpreted in a clear and systematical procedure. The result of the study, which is about parental participation, has revealed that there are more quantitative studies, scanning pattern is used and also the emphasis is on preschool level. Studies were mostly conducted in Western provinces and written as an article. In recent years, there has been an increase in the studies for parental involvement.
\end{abstract}

$\underline{\text { Key Word }}$

Parental involvement, Parent-school cooperation, Document analysis.

\footnotetext{
Atıf için:

Artan-Yücetaş, G., \& Kahramanoğlu, R. (2020). Eğitimde veli katılımına yönelik çalışmaların For Citation incelenmesi. Muğla Sitkı Koçman Üniversitesi Eğitim Fakültesi [MSKU Journal of Education], 7(2),

Received: 23.07.2019 Accepted: 02.09.2020 $\quad$ Published: 01.11.2020

${ }^{1}$ Bu çalışma Gaziantep Üniversitesi Eğitim Bilimleri Enstitüsü Eğitim Bilimleri alanlında Doç. Dr. Recep KAHRAMANOĞLU danışmanlığında Gözde YÜCETAŞ ARTAN tarafindan yüksek lisans tezi olarak hazırlanmıştır.

${ }^{2}$ MEB,gzdycts@gmail.com, ORCID:0000-0002-7519-6875

${ }^{3}$ Gaziantep Üniversitesi, recepkahramanoglu@gmail.com, ORCID:0000-0001-6670-8165
} 
Anne ve babalar şüphesiz çocuklarına en yakın olup onları en iyi tanıyanlardır. Çocuklarının nasıl bir yapıya sahip olduklarını, neye ilgi duyduklarını, onlara nasıl yaklaşılması gerektiğini iyi bilirler. Bu bilgileri öğretmenlerle paylaşırlarsa öğretmenler öğrenciyi daha yakından tanımış olup ona göre davranırlar. Öğrencide potansiyel bir sorun olabilecek durum varsa bunu önleyici yaklaşımla engelleyebilirler (Özdinç, 2014). Bu da anne babaların eğitim sürecine katılımı ile gerçekleşebilir. Aile katılımı, anne babaların çocuklarının gelişim ve eğitimlerine katkıda bulunmaları için yapmış oldukları etkinliklerin bütünüdür (Ömeroğlu ve Yaşar, 2005). Aile katılımı sağladığı faydalar açısından eğitimin vazgeçilmez bir parçasıdır. Öğrencinin hem bireysel gelişiminde hem de sosyalleşmesinde önemli yere sahiptir. Kaliteli bir eğitim için öğretmen, aile, okul ve bunların iş birliği önemli ögelerdir. Bu iş birliği, öğrencinin her alanda başarısı açısından dikkate alınmalıdır. Tek taraflı çaba ve çalışma ile hedefe ulaşmanın zor olduğu ifade edilebilir. Çünkü öğrencinin okul başarısını etkileyen ve çok yönlü gelişimini sağlayan pek çok etken mevcuttur. Bunların başında en etkili etken olan aile gelir. Velilerin çocuklarıyla kuracakları iletişim ve okulla yapacakları iş birliği çocuğa büyük katkılar sağlayacaktır (Akkabak Yıldız, 2018; Albez, 2016; Albez ve Ada, 2017; Çalışkan ve Ayık, 2015; Gül, 2007; Yıldırım, 2012). Başarılı bir okul sistemi ve verimli bir ders ancak okuldaki çalışanların ve okula destek veren velilerin iş birliği içinde olmaları ile gerçekleşir.

Veli katılımının öğrenci, aile, öğretmen ve kurum açısından pek çok faydası vardır. Öğrenci, güvenli bir eğitim-öğretim ortamında daha başarılı olur. Topluma uyum sağlar. Benlik saygısı gelişir. Aile, çocuğuyla sağlıklı bir iletişim kurmaya başlar. Çocuğuna çok yönlü katkıda bulunur. Öğretmen, aile katılımı sayesinde hedefine ulaşır. Sorumluluğunu paylaşır. Bireysel farklılıkları fark eder. Kurum, fırsat eşitliğini sağlar. Eğitimde süreklilik ve kalite sağlar (Cömert ve Güleç, 2004, s.135-136; Gülcan ve Taner, 2011; Kays1l1, 2008). Bu faydalardan yararlanabilmek için velilerin eğitim sürecine etkin katılımı gerekmektedir. Bunun için pek çok seçenek vardır. Bunlar: veli toplantıları, bireysel görüşmeler, whatsapp grupları yoluyla görüşme, telefon görüşmesi, portfolyo, ev ziyaretleri, panolar, bültenler, dergiler, konferanslar, kitapçıklar, dilek istek kutusu vb. (Binicioğlu, 2010; Can, 2009; Çalışkan ve Ayık, 2015; Oktay, Gürkan, Zembat ve Unutkan, 2003). Veliler bu seçeneklerle eğitime katılabilir ve sürece büyük katkılar sağlayabilir.

Velileri eğitim sürecine katmak isteyen öğretmen iş birliği sürecini iyi bilmeli, ihtiyaçlara uygun program belirleyip süreci takip etmeli, velilerin sorularına açık ve net cevap vermelidir. Yöneticiler ise öğretmenlere bir yol haritası çizip onlara rehberlik etmeli, öğretmenlere ve velilere destek vermelidir. Aile katılım sürecinde aile ise sorumluluklarını yerine getirmeli, toplantılara katılıp gerektiğinde yeni fikirler üretmeli ve süreci, amacı desteklemelidir (Canpolat, 2011; Göktaş, 2015; Oktay ve diğ., 2003). Öğretmen, veli ve yöneticiler olumlu tutumlar geliştirmelidir. Ayrıca öğretmen veya yönetici veli katılım sürecini planlarken öncelikle ihtiyaçları belirlemeli ve ihtiyaçlar doğrultusunda da bir hedef ortaya koymalıdır. Hedefe ulaşmak için etkinlikler yapılmalı, bunlar uygulamaya dökülmeli ve son olarak süreç değerlendirilmelidir. Başarılı bir aile katılımı; iyi planlanmış, çok yönlü, iş birliğiyle gerçekleşendir.

Veli katılımının öğrencinin gelişimi açısından bu kadar önemli olmasına ve etkin veli katılımı için neler yapılması gerektiğinin farkında olunması rağmen Türkiye'de velilerin eğitime katılımı yeteri düzeyde değildir (Albez ve Ada, 2017; Albez, 2016; Can, 2009; Şahin ve Ünver, 2005). Bu durumun nedenleri arasında yoğun iş temposu, evdeki diğer çocuklar, ekonomik zorluklar, katılım süreci hakkında bilgi sahibi olmamaları, sağlık problemleri, öğretmenlerin katılıma teşvik etmemesi, öz güven eksikliği, ulaşım zorluğu vb. gösterilmektedir. İlave olarak veli toplantılarının da amaca hizmet etmediği söylenebilir. Velilerin toplantılara katılımını engelleyen unsurlar: ilgisizlik, okulun para talebi, olumsuz ögretmen tutumları olarak sıralanabilir (Albez ve Ada, 2017).

Eğitimde veli katılımı konusunun çocukların tüm gelişim alanlarında olumlu etkisi olduğunu ifade eden çalışmaların (Çakmak, 2010; Göktaş, 2015; Kahraman, 2012; Kaysıl1, 2008; Kızıltaş, 2009; Toran ve Özgen, 2018; ) yanında veli katılımı konusunda sorunlarla da karşılaşılmaktadır. Bu bağlamda, veli katılımı konusunda yapılan çalışmalar ele alındığından ilgili konuya bütüncül bir bakış açısı oluşturması önemlidir. Bundan sonra veli katılımıyla ilgili yapılacak çalışmalara yol gösterici nitelikte olması düşünülmektedir. Ayrıca çalışmada, makale ve tezlerin incelenmesi açısından oldukça kapsamlı veriler sunabilir. Bu çalışma eğitime veli katılımı gibi geniş bir konunun her yönünü kapsaması bakımından önemlidir. Bu çerçevede, çalışmada 2000-2018 yılları arasında eğitimde veli katılımı konusunda yapılmış araştırmaların incelenmesi amaçlanmaktadır. Bu amaç doğrultusunda 2000-2018 yılları arasında eğitimde veli katılımı konusunda Türkçe yazılmış makale, yüksek lisans ve 
doktora tezinden oluşan 144 çalışma incelenmiştir. Bu amaç çerçevesinde aşağıdaki sorulara yanıt aranmiştır.

1. 2000-2018 yılları arasında eğitimde veli katılımı konusunda yapılmış çalışmaların amacı nedir?

2. 2000-2018 yılları arasında eğitimde veli katılımı konusunda yapılmış çalışmaların yapıldığı yer neresidir?

3. 2000-2018 yılları arasında eğitimde veli katılımı konusunda yapılmış çalışmaların yayın yılı nedir?

4. 2000-2018 yılları arasında eğitimde veli katılımı konusunda yapılmış çalışmaların yapıldı̆̆ı kademe nedir?

5. 2000-2018 yılları arasında eğitimde veli katılımı konusunda yapılmış çalışmaların türü nedir?

6. 2000-2018 yılları arasında eğitimde veli katılımı konusunda yapılmış çalışmaların yöntemi nedir?

7. 2000-2018 yılları arasında eğitimde veli katılımı konusunda yapılmış çalışmaların deseni nedir?

8. 2000-2018 yılları arasında eğitimde veli katılımı konusunda yapılmış çalışmaların veri toplama arac1 nedir?

\section{Yöntem}

\section{Araștırmanın Modeli}

Araştırmada veli katılımı konusunda alan yazında yapılmış çalışmaların incelenmesi amaçlandığı için nitel araştırma yöntemlerinden doküman incelemesi yöntemi kullanılmıştır. Doküman incelemesi yapılırken dikkate alınıp sırayla izlenmesi gereken aşamalar vardır. Bu aşamalar: dokümanlara ulaşma, dokümanların orijinalliğini kontrol etme, dokümanları anlama, veriyi analiz etme, veriyi kullanma (Yıldırım- Şimşek, 2016, s.94).

\section{Veri Kaynakları}

Çalışma kapsamında eğitimde veli katılımı konusunda 2000-2018 yılları arasında Türkçe yazılmış makaleler, yüksek lisans tezleri ve doktora tezleri doküman olarak incelenmiştir. Bu dokümanlara ulaşabilmek için Ulusal Tez Merkezi, Google Akademik, Ulakbim, Dergipark gibi sitelerde alanyazın taraması yapılmıştır. Tarama yapılırken "aile katılımı, veli katılımı, okul aile iş birliği, veli iş birliği" anahtar sözcükleri kullanılmıştır. Elde edilen dokümanların bazıları İngilizce olduğu için araştırmaya dâhil edilmemiştir. Bazı dokümanların ise veri tabanı üzerinden yayınlanma izni bulunmadığı için yazarlarına erişim sağlanamadığından çalışmaya dâhil edilmemiştir. Doküman incelemesi yöntemiyle gerçekleştirilen bu çalışmada 72 makale, 63 yüksek lisans tezi, 9 doktora tezi üzerinde çalışma sürdürülmüştür.

Ele alınan tezler ve makaleler excel dosyasında sınıflandırılmış ve açıklamaları yapılmıştır. Excel dosyasına sırasıyla çalışmanın adı, çalışmanın konusu, çalışmanın yazarı, çalışmanın yapıldığı yer, çalışmanın çeşidi, örneklem sayısı, çalışmanın yayın yılı, veri toplama aracı, araştırma deseni, araştırmanın yapıldığı kademe, çalışmanın türü ve çalışmanın amacı yazılmıştır. Bu yöntemle 144 çalışma incelenmiş elde edilen bilgiler excele girilmiştir.

\section{Veri Analizi}

$\mathrm{Bu}$ çalışmada, doküman incelemesinden elde edilen verilerin analizinde betimsel analiz yöntemi kullanılmıştır. Betimsel analiz dört aşamadan oluşur: Çerçeve oluşturma, çerçeveye göre verilerin işlenmesi, bulguların tanımlanması, bulguların yorumlanması (Yıldırım ve Şimşek, 2016, s. 240). Betimsel analiz yapılırken öncelikle bir çerçeve oluşturulur. Bu çerçeve doğrultusunda veriler, temaların altlarına yerleştirilir. Oluşturulan çerçeveye göre veriler düzenlenir, anlamlı ve mantıklı bir hale getirilir. Ardından veriler tanımlanır ve bu tanımlar doğrudan alıntılarla desteklenir. Son olarak bulgular açıklanır, ilişkilendirilir ve anlamlandırılır (Yıldırım ve Şimşek, 2016, s. 240). Bu araştırmada veriler, belirli temalar altında düzenlenmiş ve tanımlanmıştır. Betimlemeler alıntılar yoluyla zenginleştirilmiştir. Belirlenen temalar altında bulgular düzenlenmiştir. Betimlemelerden yola çıkılarak yorumlar yapılmıştır.

Araştırma çerçevesinde sekiz tema belirlenmiştir. Bunlar: çalışmanın yapıldığ 1 yer, çalışmanın yöntemi, çalışmanın yayın yılı, veri toplama aracı, araştırma deseni, araştırma yapılan kademe, çalışma türü ve araştırmanın amacı. Bu temalar altında 144 çalışma incelenmiş, veriler işlenmiş, bulgular tanımlanmış ve yorumlanmıştır. 


\section{Geçerlik- Güvenirlik}

$\mathrm{Bu}$ çalışmada veriler yansız olarak ele alınmıştır ve gerçeği yansıtmaktadır. Eğitime veli katılımı konusunda yapılan çalışmalar ele alınmış ve değerlendirilmiş olup elde edilen bulgular kuramsal çerçeveye uygundur. Aynı zamanda ortaya çıkan kavramlar kendi arasında anlamlı bir bütün oluşturmaktadır ve tutarlıdır. Sonuçlar, araştırma sorularıyla ilgili kuramlarla tutarlıdır. Veriler eleştirel bir yolla elde edilmiştir. Sonuçlar denetlendikten sonra sonuç raporları elde edilmiş bunlar da genellenebilir özellikte ve tutarlı hale getirilmiştir. Öncelikle 2000-2018 y1lları arasında eğitime veli katılımı konusunda yapılan araştırmalar bulunmuş; problem durumu, araştırmanın önemi, amacı, alt problemler belirlenmiş; çalışmalar hakkında detaylı bilgi alt problemlere göre excelde tablolaştırılmıştır. Ardından bu bilgilere bulgular kısmında tarafsız olarak yer verilmiştir. Bulgular tartışma kısmında değerlendirilmiş sonuç ve öneriler kısmında bir karara bağlanıp tavsiyeler sunulmuştur. Kuramsal çerçeve kısmında veli katılımı ve boyutlarıyla ile ilgili detaylı bilgiler kaynak gösterilerek verilmiştir. Bunlar araştırmanın geçerliğini olumlu etkilemektedir.

Çalışmanın yöntemine, aşamalarına, araştırma sorularına, sonuçlara açık ve ayrıntılı şekilde yer verilerek dış güvenirlik sağlanmıştır. Ön yargılar ve şahsi varsayımlar sonucu etkilememiştir. Elde edilen veriler yorum katılmadan nesnel şekilde ifade edilmiştir. Bunlar iç güvenirliği olumlu etkilemektedir. Veriler ayrıntılı ve amaca uygun şekilde hazırlanmış olup sonuçlarla uyumludur. Geçerli olmayan veriler ayıklanmıştır. Yanlış anlaşılmaya mahal verecek cümlelere yer verilmemiştir. Veriler açık, tutarlı ve teyit edilebilir özelliktedir. Bunlar araştırmanın güvenirliğini olumlu etkilenmektedir. Ayrıca çalışmanın tüm aşamasında geçerliğe ve güvenirliğe yönelik tedbirler alınmıştır.

\section{Bulgular}

Çocukların etkili bir eğitim alabilmesi açısından öğretmen ve veli iş birliği büyük önem taşır. $\mathrm{Bu}$ çalışmanın bulguları "Eğitimde veli katılımı" konusunda yapılan araştırmalar incelenerek elde edilmiştir. Elde edilen veriler tablolaştırılmıştır. Bu bölümde araştırmanın alt problemlerine ilişkin bulgulara yer verilmiştir.

\section{Eğitimde Veli Katılımı Konusunda Yapılmış Çalışmaların Amacına Yönelik Bulgular}

2000-2018 yılları arasında eğitimde veli katılımı konusunda yazılmış makale, yüksek lisans tezi ve doktora tezlerinin amaçları irdelenmiş sonuçlar aşağıdaki tabloda gösterilmiştir.

Tablo 1'de eğitiminde veli katılımı konusunda yapılan çalışmaların amaçlarına ait frekans ve yüzdelere yer verilmiştir. 144 çalışmada 30 ayrı amaç tespit edilmiştir. 38 çalışmanın amacı: Öğretmenlerin, ailelerin, okul müdürlerinin ve öğretim görevlilerinin aile katılımı hakkında görüşlerinin belirlenmesidir. 14 çalı̧̧manın amacı: Aile katılımı ve önemi hakkında bilgi vermek, öneriler sunmaktır. 10 çalışmanın amacı: Aile katılımının öğrenci başarısına etkisini ortaya koymaktır. 9 çalışmanın amacı: Çeşitli değiş̧kenler açısından aile katılımını incelemektir. 7 çalışmanın amacı: Aile katılımının öğrencinin sosyal becerisine etkisini incelemektir. 7 çalışmanın amacı: Veli katılım düzeylerini belirlemektir. 6 çalışmanın amacı: Okul aile iş birliği düzeyini belirlemektir. 5 çalışmanın amacı: Aile Katılım Ölçeğini (AKÖ) Türkçeye uyarlamaktır. 4 çalışmanın amacı: Baba katılımının eğitimdeki yerini belirlemektir. 4 çalışmanın amacı: Aile katılım çalışmalarının incelenmesidir. 3 çalışmanın amacı: Okul ile aile arasındaki sorumlulukları, sorunları ve beklentileri belirlemektir. 3 çalışmanın amacı: Okul aile birliklerinin etkililiği belirlemektir. 3 çalışmanın amacı: Aile katılım stratejileri belirlemektir. 3 çalışmanın amacı: Aile katılımının öğrencinin öz yeterlik düzeyine etkisini incelemektir. 2 çalışmanın amacı: Aile katılımının dil becerisine etkisini araştırmaktır. 2 çalışmanın amacı: Aile katılımı konusunda ebeveyn tutumları belirlemektir. 2 çalışmanın amacı: Aile katılımının öğrencinin akademik benlik saygısı düzeyine etkisini belirlemektir. 2 çalışmanın amacı: Veli ilgisinin SBS puanına etkisini belirlemektir. 2 çalışmanın amacı: Aile katılımının hazırbulunuşluk düzeyine etkisini ortaya koymaktır. 2 çalışmanın amacı: Aile katılımının öğrencinin saygı düzeyine etkisini ortaya koymaktır. 1 çalışmanın amacı: Aile katılımı konusunda farkındalıkların belirlenmesidir. 1 çalışmanın amacı: Aile katılım eğitiminin etkisini belirlemektir. 1 çalışmanın amacı: Aile katılım konusunda teknolojinin kullanımını belirlemektir. 1 çalışmanın amacı: Liderlik, aile katılımı ve okula bağlılık arasındaki ilişkiyi belirlemektir. 1 çalışmanın amacı: Öğrencilerin ödev yapma düzeyleri ile aile katılımı arasındaki ilişkiyi belirlemektir. 1 çalışmanın amacı: Aile katılımının okuma becerisine 
etkisini belirlemektir. 1 çalışmanın amacı: Aile katılımının okula aidiyet duygusuna etkisini belirlemektir. 1 çalışmanın amacı: Aile katılımı programının etkililiğini araştırmaktır.

Tablo 1

Ĕ̈itimde Veli Katılımı Konusunda Yapılmış Çalışmaların Amaçlarına Ait Frekans ve Yüzdeler

\begin{tabular}{|c|c|c|c|}
\hline No & Amaçlar & f & $\%$ \\
\hline 1 & $\begin{array}{l}\text { Öğretmenlerin, ailelerin, okul müdürlerinin ve öğretim görevlilerinin aile katılımı hakkında } \\
\text { görüşlerinin belirlenmesi. }\end{array}$ & 38 & 26.38 \\
\hline 2 & Aile katılımı ve önemi hakkında bilgi vermek, öneriler sunmak. & 14 & 9.72 \\
\hline 3 & Aile katılımının öğrenci başarısına etkisini ortaya koymak & 10 & 6.94 \\
\hline 4 & Çeşitli değişkenler açısından aile katılımını incelemek. & 9 & 6.25 \\
\hline 5 & Aile katılımının öğrencinin sosyal becerisine etkisini belirlemek. & 7 & 4.86 \\
\hline 6 & Veli katılım düzeylerini belirlemek. & 7 & 4.86 \\
\hline 7 & Okul aile iş birliği düzeyini belirlemek. & 6 & 4.16 \\
\hline 8 & Aile Katılım Ölçeğini (AKÖ) Türkçeye uyarlamak. & 5 & 3.47 \\
\hline 9 & Aile katılımı konusunda öğretmen tutumları belirlemek. & 4 & 2.77 \\
\hline 10 & Veli toplantıları hakkında bilgi vermek. & 4 & 2.77 \\
\hline 11 & Baba katılımının eğitimdeki yerini belirlemek. & 4 & 2.77 \\
\hline 12 & Aile katılım çalışmalarının incelenmesi. & 4 & 2.77 \\
\hline 13 & Aile katılımının öğrencinin öz yeterlik düzeyine etkisi. & 3 & 2.08 \\
\hline 14 & Aile katılım stratejileri belirlemek. & 3 & 2.08 \\
\hline 15 & Okul aile birliklerinin etkililiği belirlemek. & 3 & 2.08 \\
\hline 16 & Okul ile aile arasındaki sorumlulukları, sorunları ve beklentileri belirlemek. & 3 & 2.08 \\
\hline 17 & Aile katılımının öğrencinin saygı düzeyine etkisi. & 2 & 1.38 \\
\hline 18 & Aile katılımının dil becerilerine etkisini belirlemek. & 2 & 1.38 \\
\hline 19 & Aile katılımı konusunda ebeveyn tutumları belirlemek. & 2 & 1.38 \\
\hline 20 & Veli ilgisinin SBS puanına etkisini belirlemek. & 2 & 1.38 \\
\hline 21 & Aile katılımının öğrencinin akademik benlik saygısı düzeyine etkisini belirlemek. & 2 & 1.38 \\
\hline 22 & Aile katılımının hazırbulunuşluk düzeyine etkisi. & 2 & 1.38 \\
\hline 23 & Aile katılımı programının etkililiğini araştırmak. & 1 & 0.69 \\
\hline 24 & Aile katılımının okuma becerisine etkisi. & 1 & 0.69 \\
\hline 25 & Aile katılımının okula aidiyet duygusuna etkisi. & 1 & 0.69 \\
\hline 26 & Öğrencilerin ödev yapma düzeyleri ile aile katılımı arasındaki ilişkiyi belirlemek. & 1 & 0.69 \\
\hline 27 & Liderlik, aile katılımı ve okula bağl1lık arasındaki ilişkiyi belirlemek. & 1 & 0.69 \\
\hline 28 & Aile katılım eğitiminin etkisini belirlemek. & 1 & 0.69 \\
\hline 29 & Aile katılım konusunda teknolojinin kullanımı. & 1 & 0.69 \\
\hline 30 & Aile katılımı konusunda farkındalıkların belirlenmesi. & 1 & 0.69 \\
\hline
\end{tabular}

\section{Eğitimde Veli Katılımı Konusunda Yapılmış Çalışmaların Yapıldığı Yerlere Yönelik Bulgular}

2000-2018 yılları arasında eğitimde veli katılımı konusunda yazılmış makale, yüksek lisans tezi ve doktora tezlerinin yapıldığı yerler araştırılmış sonuçlar aşağıdaki tabloda gösterilmiştir.

Tablo 2'de eğitiminde veli katılımı konusunda yapılan çalışmaların yapıldığı yerlere ait frekans ve yüzdelere yer verilmiştir. 144 çalışmanın 125 'inde yer bulunmaktadır. Çalışmaların yapıldığ yerler: İzmir, Burdur, İstanbul, Bursa, Çanakkale, Afyonkarahisar, Ankara, Kastamonu, Mersin, Yalova, Balıkesir, Malatya, Erzurum, Diyarbakır, Konya, Erzincan, Denizli, Manisa, Sivas, Kayseri ve Eskişehir illeridir. En çok çalışma yapılan şehir 20 çalışma ile İstanbul'dur. Ardından 18 çalışma ile Ankara gelir. Ardından 8 çalışma ile Eskişehir gelir. Çalışmaların çoğunlukla büyük şehirlerde gerçekleştiği görülmektedir. Çalışmaların biri Türkiye genelinde yapılmıştır. Bir çalışma ise şehir ismi söylenmeden Ege bölgesinde bir ilde yapılmıştır. 
Tablo 2

Ĕ̈itimde Veli Katılımı Konusunda Yapılmış Çalışmaların Yapıldı̆̆ı Yerlere Ait Frekans ve Yüzdeler

\begin{tabular}{cccc} 
No & Yer & $\mathrm{f}$ & $\%$ \\
\hline 1 & İstanbul & 20 & 16 \\
2 & Ankara & 18 & 14.4 \\
3 & Eskişehir & 8 & 6.4 \\
4 & Denizli & 7 & 5.6 \\
5 & Erzurum & 5 & 4 \\
6 & Kastamonu & 4 & 3.2 \\
7 & Mersin & 4 & 3.2 \\
8 & İzmir & 4 & 3.2 \\
9 & Konya & 4 & 3.2 \\
10 & Manisa & 3 & 2.4 \\
11 & Afyonkarahisar & 3 & 2.4 \\
12 & Çanakkale & 2 & 1.6 \\
13 & Sivas & 2 & 1.6 \\
14 & Kayseri & 2 & 1.6 \\
15 & Erzincan & 2 & 1.6 \\
16 & Yalova & 2 & 1.6 \\
17 & Bursa & 1 & 0.8 \\
18 & Burdur & 1 & 0.8 \\
19 & Türkiye geneli & 1 & 0.8 \\
20 & Balıkesir & 1 & 0.8 \\
21 & Malatya & 1 & 0.8 \\
22 & Diyarbakır & 1 & 0.8 \\
23 & Ege bölgesinde bir il & 1 & 0.8 \\
\hline
\end{tabular}

Eğitimde Veli Katılımı Konusunda Yapılmış Çalışmaların Yıllarına Yönelik Bulgular

2000-2018 yılları arasında eğitimde veli katılımı konusunda yazılmış makale, yüksek lisans tezi ve doktora tezlerinin yapıldığı yıllar araştırılmış sonuçlar aşağıdaki tabloda gösterilmiştir.

Tablo 3

Eğitimde Veli Katılımı Konusunda Yapılmış Çalışmaların Yapıldı̆̆ı Yıllara Ait Frekans ve Yüzdeler

\begin{tabular}{cccc}
\hline No & Yayın Yılı & f & $\%$ \\
\hline 1 & 2018 & 15 & 10.41 \\
2 & 2014 & 14 & 9.72 \\
3 & 2017 & 13 & 9.02 \\
4 & 2016 & 13 & 9.02 \\
5 & 2010 & 12 & 8.33 \\
6 & 2008 & 10 & 6.94 \\
7 & 2012 & 10 & 6.94 \\
8 & 2013 & 9 & 6.25 \\
9 & 2015 & 9 & 6.25 \\
10 & 2011 & 8 & 5.55 \\
11 & 2007 & 7 & 4.86 \\
12 & 2009 & 6 & 4.16 \\
13 & 2006 & 5 & 3.47 \\
14 & 2004 & 5 & 3.47 \\
15 & 2002 & 2 & 1.38 \\
17 & 2003 & 2 & 1.38 \\
18 & 2005 & 2 & 1.38 \\
19 & 2000 & 1 & 0.69 \\
& 2001 & 1 & 0.69 \\
\hline
\end{tabular}

Tablo 3'te eğitiminde veli katılımı konusunda yapılan çalışmaların yıllarına ait frekans ve yüzdelere yer verilmiştir. En fazla çalışmanın 2018 yılında yapıldığı görülmektedir. Genel olarak değerlendirildiğinde veli katılımı konusunda son 10 yıl içinde artış olduğu ortaya çıkmıştır. 


\section{Eğitimde Veli Katılımı Konusunda Yapılmış Çalışmaların Yapıldığı Kademelere Yönelik Bulgular}

2000-2018 yılları arasında eğitimde veli katılımı konusunda yazılmış makale, yüksek lisans tezi ve doktora tezlerinin yapıldığı kademeler araştırılmış sonuçlar aşağıdaki şekil 1'de gösterilmiştir.

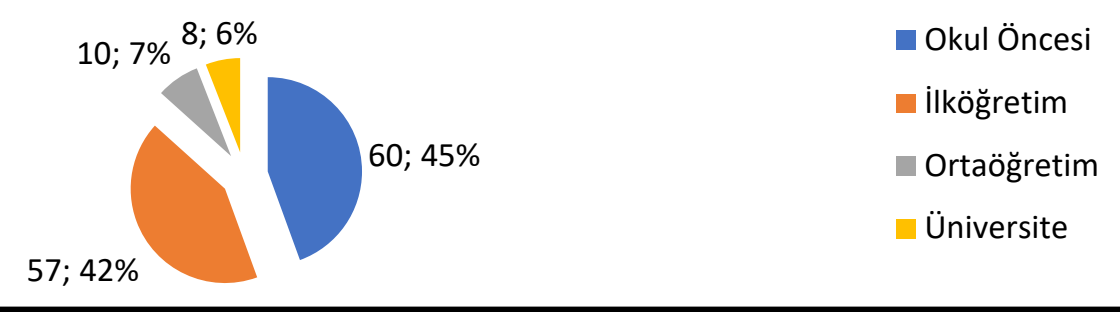

Şekil 1. Eğitimde Veli Katılımı Konusunda Yapılmış Çalışmaların Yapıldığı Kademeler

Şekil 1'de eğitiminde veli katılımı konusunda yapılan çalışmaların hangi kademelerde yapıldığına dair frekans ve yüzdelere yer verilmiştir. 144 çalışmanın 60'1 okul öncesi, 57'si ilköğretim, 10'u ortaöğretim, 8'i üniversite kademesinde yapılmıştır. Görüldüğü gibi kademe yükseldikçe yapılan çalışmalar azalmıştır. Çalışmaların büyük bir kısmı okul öncesi ve ilköğretim kademesinde yapılmıştır.

\section{Eğitimde Veli Katılımı Konusunda Yapılmış Çalışmaların Türlerine Yönelik Bulgular} 2000-2018 yılları arasında eğitimde veli katılımı konusunda yazılmış makale, yüksek lisans tezi ve doktora tezlerinin çalışma türleri araştırılmış sonuçlar şekil 2'de verilmiştir.

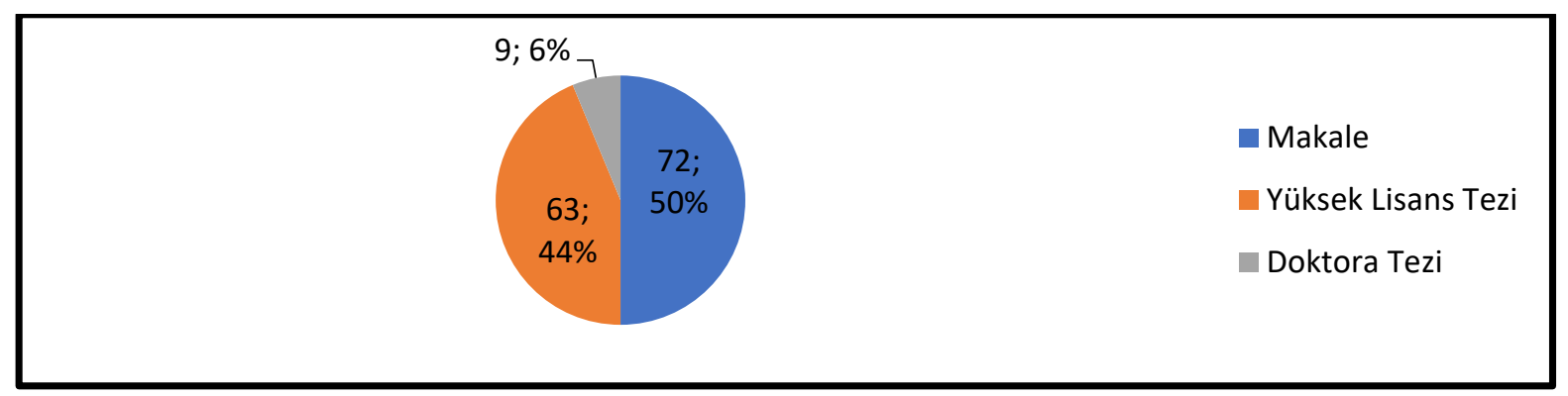

Şekil 2. Eğitimde Veli Katılımı Konusunda Yapılmış Çalışmaların Türü

Şekil 2'de eğitiminde veli katılımı konusunda yapılan çalışmaların türlerine ait frekans ve yüzdelere yer verilmiştir. 144 çalışmadan yarısı makaledir. 63 çalışma yüksek lisans tezi, 9 çalışma ise doktora tezidir. Eğitimde veli katılımı konusunda daha çok makale yazılmıştır.

\section{Eğitimde Veli Katılımı Konusunda Yapılmış Çalışmaların Yöntemlerine Yönelik Bulgular}

2000-2018 yılları arasında eğitimde veli katılımı konusunda yazılmış makale, yüksek lisans tezi ve doktora tezlerinde kullanılan yöntemler araştırılmış sonuçlar şekil 3'te gösterilmiştir.

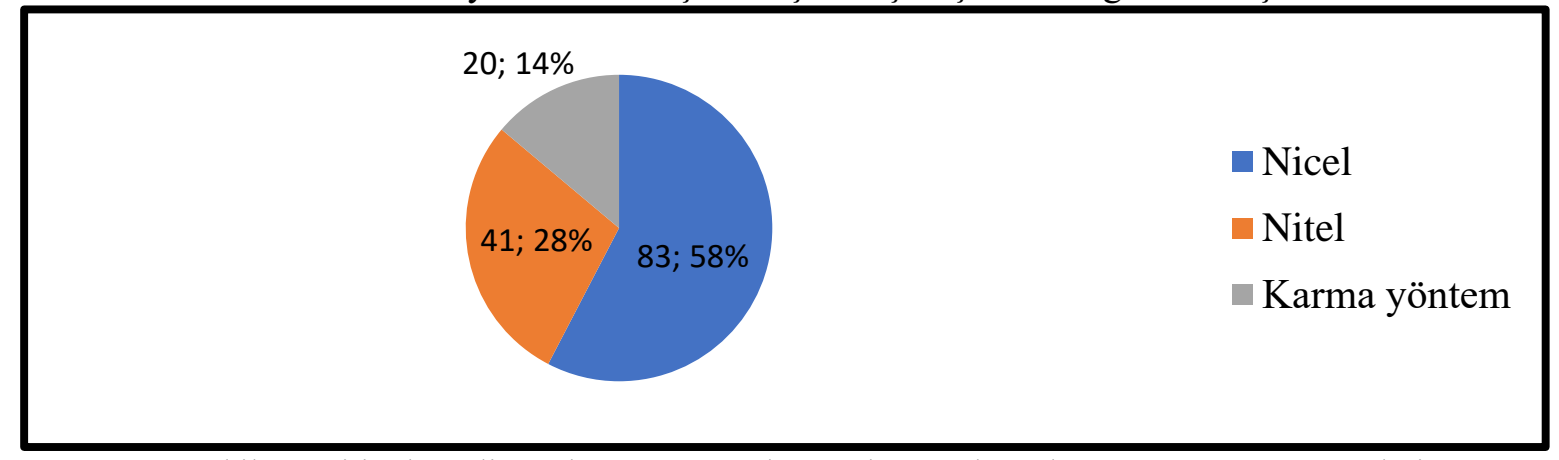

Şekil 3. Eğitimde Veli Katılımı Konusunda Yapılmış Çalışmaların Araştırma Yöntemleri

Şekil 3'te eğitiminde veli katılımı konusunda yapılan çalışmaların yöntemlerine ait frekans ve yüzdelere yer verilmiştir. Eğitimde veli katılımı konusunda yapılan 144 çalışmadan 83'ü nicel 
araştırma yöntemiyle, 41'i nitel araştırma yöntemiyle, 20'si ise hem nicel hem nitel araştırma yöntemiyle yazılmıştır.

Eğitimde Veli Katılımı Konusunda Yapılmış Çalışmaların Desenlerine Yönelik Bulgular 2000-2018 yılları arasında eğitimde veli katılımı konusunda yazılmış makale, yüksek lisans tezi ve doktora tezlerinde kullanılan desenler araştırılmış sonuçlar tablo 4 'te verilmiştir.

Tablo 4

Eğitimde Veli Katılımı Konusunda Yapılmış Çalışmaların Araştırma Desenlerine Ait Frekans ve Yüzdeler

\begin{tabular}{cccc}
\hline No & Araştırma Deseni & f & $\%$ \\
\hline 1 & Tarama deseni & 47 & 23.61 \\
2 & Betimsel desen & 28 & 23.52 \\
3 & Deneysel desen & 18 & 15.12 \\
4 & Durum çalışma deseni & 8 & 6.72 \\
5 & Karma desen & 8 & 6.72 \\
6 & Olgubilim (Fenomenoloji) yaklaşımı & 3 & 2.52 \\
7 & Nedensel karşlaştırma deseni & 2 & 1.68 \\
8 & Ölçek geliştirme- uyarlama & 1 & 0.84 \\
9 & Temel yorumlayıcı desen & 1 & 0.84 \\
10 & Alan araştırması & 1 & 0.84 \\
11 & Kesitsel betimleme deseni & 1 & 0.84 \\
12 & Eylem araştırmasi deseni & 1 & 0.84 \\
\hline
\end{tabular}

Tablo 4'te eğitiminde veli katılımı konusunda yapılan çalışmaların desenlerine ait frekans ve yüzdelere yer verilmiştir. 144 çalışmanın 119'unda araştırma deseni bulunmaktadır. Bu çalışmaların 47'sinde tarama deseni, 28'inde betimsel desen, 18'inde deneysel desen, 8'inde durum çalışması deseni, 8'inde karma desen, 3'ünde fenomenoloji deseni, 2'sinde nedensel karşılaştırma deseni, 1'inde eylem araştırması deseni, 1'inde doğrulayıcı faktör analizi, 1'inde kavramsal durum analizi, 1'inde alan araştırması, 1'inde kesitsel betimleme deseni, 1'inde temel yorumlayıcı desen kullanılmıştır.

\section{Eğitimde Veli Katılımı Konusunda Yapılmış Çalışmaların Veri Toplama Araçlarına} Yönelik Bulgular

2000-2018 yılları arasında eğitimde veli katılımı konusunda yazılmış makale, yüksek lisans tezi ve doktora tezlerin veri toplama araçları araştırılmış sonuçlar şekil 4'te gösterilmiştir.

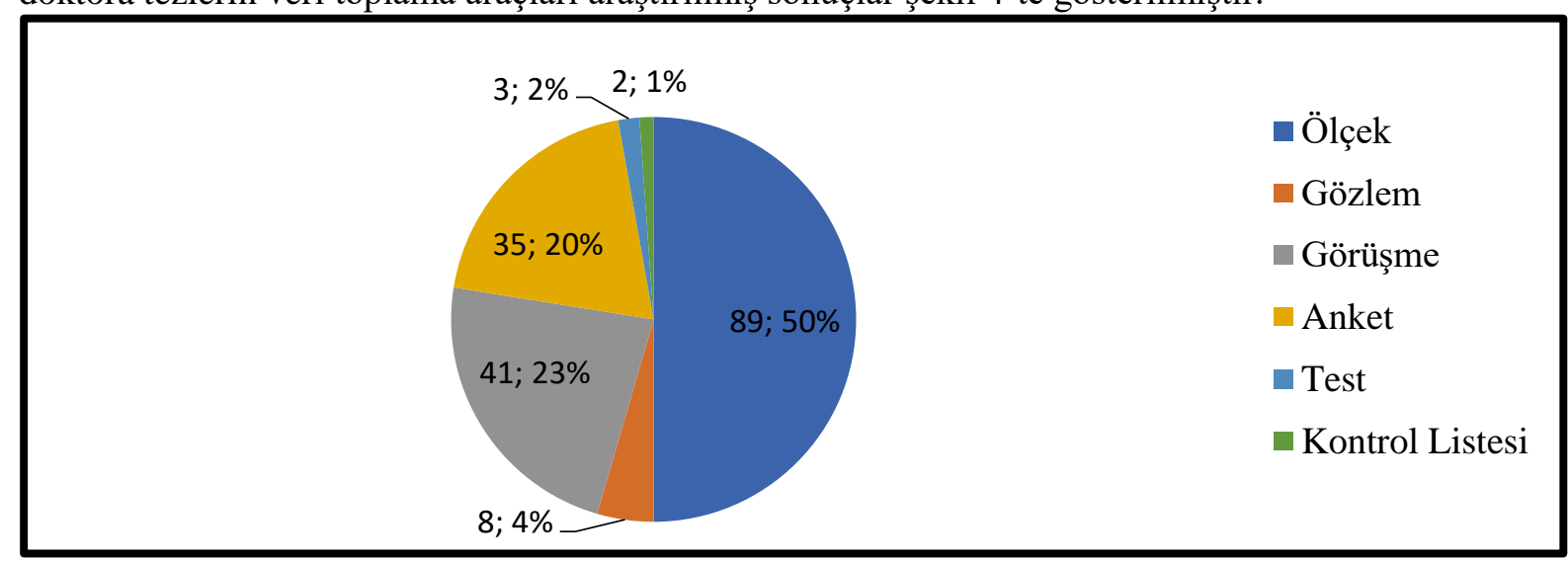

Şekil 4. Eğitimde Veli Katılımı Konusunda Yapılmış Çalışmaların Veri Toplama Araçları

Şekil 4'te eğitimde veli katılımı konusunda yapılmış çalışmalarda kullanılan veri toplama araçlarına ait frekans ve yüzdelere yer verilmiştir. 89 çalışmada ölçek, 41 çalışmada görüşme, 35 çalışmada anket, 13 çalışmada form, 8 çalışmada gözlem, 3 çalışmada günlük, 3 çalışmada test, 2 çalışmada envanter, 2 çalışmada kontrol listesi kullanılmıştır.

Çalışmalarda 33 farklı ölçek kullanılmıştır. Veri toplama araçlarından görüşmeyi kullanan çalışmaların 20'si yarı yapılandırılmış görüşme, 20'si normal görüşme, 1'i ise gösterilen fotoğrafın hikâyesini anlattırma şeklindedir. Uygulanan 3 testten biri erken matematik yeteneği testi, biri gelişimsel tarama testi, biri akademik başarı testidir. Uygulanan 2 envanterden biri öğrenci velisini okula çekme envanteri diğeri ise okul aile ilişkilerinden karşılaşılan sorunlar envanteridir. Uygulanan 2 kontrol 
listesinden biri öğretmenlerin gerçekleştirdiği aile katılım etkinlikleri kontrol listesi diğeri ise ebeveynlerin katıldıkları aile katılım etkinlikleri kontrol listesidir.

Çalışmalarda kullanılan veri toplanma araçları sayıları şekil 5'te verilmiştir.

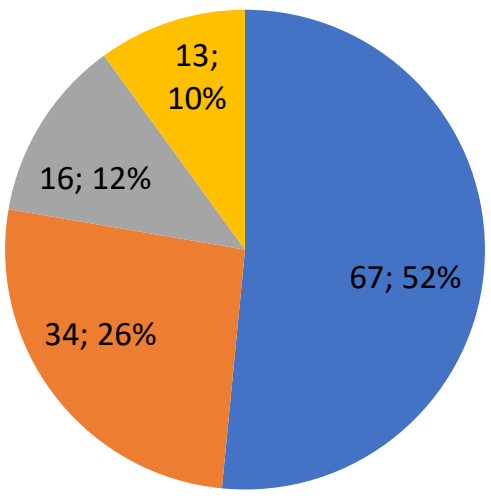

1 veri toplama araci kullanan çalışmalar

2 veri toplama aracı kullanan çalışmalar

3 veri toplama arac1 kullanan çalışmalar

4 ve daha fazla veri toplama aracı kullanan çalışmalar

Şekil 5. Eğitimde Veli Katılımı Konusunda Yapılmış Çalı̧̧malarda Kullanılan Veri Toplama Aracı Sayıları

Şekil 5 incelendiğinde, 144 çalışmanın 130'unda veri toplama aracı kullanılmıştır. Sadece 1 veri toplama aracı kullanan çalışma sayısı 67'dir. 2 veri toplama aracı kullanan çalışma sayısı 34, 3 veri toplama aracı kullanan çalışma sayısı 16, 4 ve daha fazla veri toplama aracı kullanan çalışma sayısı 13 'tür.

\section{Tartışma, Sonuç ve Öneriler}

Bu çalı̧̧mada eğitimde veli katılımı konusunda 2000-2018 yılları arasında yapılmış araştırmalar incelenmiştir. Eğitimde veli katılımı konusunda yapılmış çalışmaların pek çok amacı bulunmaktadır. $\mathrm{Bu}$ çalışmaların daha çok öğretmenlerden, öğretmen adaylarından, velilerden, okul idaresinden ve akademisyenlerden görüş almak amacıyla yapıldığı çıkarımına ulaşılmıştır. Pek çok çalışmada yer alan bir diğer amaç ise eğitimde veli katılımının öğrenci başarısına etkisini ortaya koymaktır. Ayrıca veli katılımı pek çok değişkene göre incelenmiştir. Bu değişkenler: veli katılımının öğrencinin sayg1 düzeyine, sosyal becerilerine, dil becerilerine, okuma becerilerine, farklılıklara saygı düzeylerine, öz yeterlik düzeylerine, akademik benlik saygı düzeylerine, okula aidiyet duygularına, okula hazırbulunuşluk düzeylerine, matematik başarılarına etkisi... Bazı çalışmaların amaçları ise: aile katılımı konusunda öğretmen ve ebeveyn tutumlarını belirlemek, veli katılım düzeyini belirlemek, okul aile iş birliği düzeyini belirlemek, aile katılım stratejilerini belirlemek, aile katılımı hakkında bilgi vermek, veli toplantıları hakkında bilgi vermek... şeklindedir. $\mathrm{Bu}$ amaçlar doğrultusunda çalışmalar yapılmış ve sonuçlara ulaşılmıştır.

Eğitimde veli katılımı konusunda 2000-2018 yılları arasında yapılmış çalışmaların nerede yapıldığı incelendiğinde bu çalışmaların çoğunun büyük şehirlerde ve Türkiye'nin batısında yapıldığı görülmüştür. Türkiye genelinde 22 ilde aile katılımı konusunda çalışma yapıldığı görülmektedir. En çok çalışma İstanbul'da yapılırken ardından sırasıyla Ankara, Eskişehir ve Denizli gelmektedir. En az çalışma ise bir çalışma ile Malatya'da yapılırken ardından ikişer çalışma ile Erzincan ve Sivas gelir. Büyükşehirlerde öğrenci ve veli sayısı çok olduğu için eğitime veli katılımı konusu daha çok yapılmış olabilir. Bu sayısının Güneydoğu ve Doğu Anadolu'da oldukça az olmasının nedeni velilerin okula ve eğitime karşı tutumlarının zayıf olmasından ve ailelerin çocuk sayısının çok olmasından kaynaklanıyor olabilir. Çünkü veli katılımı konusunda yapılacak olan bir bilimsel çalışmada sistematik bir sürecin oluşması gerekmektedir. Bu sistematik sürecin sağlıklı bir şekilde devam etmesi için velilerin eğitim sürecine istekli ve aktif katılımı önemlidir. Dolayısıyla velilerin eğitime yönelik tutumlarının zayıf olduğu ve ailelerin çok çocuklu olması düşünüldüğünde bu süreci tasarlamak oldukça zorlaşacaktır. Dolayısıyla -özellikle bu bölgelerde- çalışma sayısının az olması bu gerekçelere dayandırılabilir.

Eğitimde veli katılımı konusunda yapılmış çalışmaların yıllara göre dağılımı incelendiğinde çalışmaların zamanla arttığı ve en çok çalışmanın 2018 yılında yapıldığı görülmüştür. 2000 yılında 1 çalışma yapılmışken 2018 yılında 15 çalışma yapılmıştır. Çalışma sayıları genel anlamda her yıl artış göstermiştir. Türkiye'de okuryazar insan sayısının artması ve insanların eğitim seviyeleri yükseldikçe eğitime ve eğitimde veli katılımına verilen önemin daha çok ön plana çıktığı ifade edilebilir. 
Dolayısıyla veli katılımı konusundaki çalışmaların son yıllarda artış görülmesinin nedeni bu konudaki farkındalığın artması sonucu olabilir. Milli Eğitim Bakanlı̆̆ aile katılım çalışmalarına eğitim programlarında ilk kez 1952 yılında yer vermiştir. Ailenin çocuğuna karşı nasıl davranması gerektiği, veli ziyaretleri, çocuğun okula başladığı ilk andan itibaren ailenin de eğitim-öğretim ortamına katılması gerektiği gibi konulara değinilmiştir. Ailelerin bilgilendirilmesi gerektiği ifade edilmiştir. Daha sonraki programlarda ya aile katılımına yer verilmemiştir ya da birkaç cümle ile ifade edilmiştir. 1994 yılına gelindiğinde okul öncesi kurumlar için bir eğitim programı hazırlanmış ve bu programda aile katılımı konusunda detaylı bilgilendirmeler ve gereklilikler ele alınmıştır. Ardından 2002, 2006, 2013 y1llarında program güncellenmiş aile katılımının önemi her programda yinelenmiştir (Köyceğiz ve arkadaşları, 2016). Buradan da anlaşıldığı üzere aile katılım çalışmalarının yıllar geçtikçe artmasının bir sebebi de eğitim programlarında aldığı yerdir.

Eğitimde veli katılımı konusunda yapılmış çalışmaların kademelerine bakıldığında en çok okul öncesi eğitim kademesinde daha sonra ilköğretim kademesinde veli katılımı çalışmaları incelendiği görülmüştür. Kademe ilerledikçe çalışma sayısının azaldığı sonucuna varılmıştır. Üniversite kademesinde yapılan çalışmaların ise üniversite öğrencilerinin ailelerinin katılımı şeklinde değil de üniversitede eğitim fakültelerinde okuyan öğretmen adaylarının veli katılımı konusundaki bilgileri ve tutumları ölçülmek amacıyla yapıldığı görülmüştür. Milli Eğitim Bakanlığının 2006 yılında çıkardığı "Okul Öncesi Eğitim Programında" okul aile iş birliği ile aile katılımının önemini vurgulanmış, aile katılımlı programlarda yetişen çocukların kalıcı ve olumlu özellikler kazandıkları ifade edilmiştir. Ayrıca çocukların kazandığı becerileri günlük yaşama daha kolay aktarabileceği vurgulanmıştır (Çakmak, 2010). Milli Eğitim Bakanlığının hazırladığı bu programdan sonra aile katılımına önem verilip bu konuda yapılan çalışmaların arttı̆̆ı görülmüştür. Bundan dolayı okul öncesi eğitim kademesinde aile katılımının önemi fark edilip üzerine çalışmalar yapılmıştır. Ayrıca küçük yaş grubunda bulunan çocukların örgün eğitim sürecine girdiği andan itibaren diş desteğe yani aile desteğine ihtiyaç duymaktadır. Gerek zihinsel gelişim özellikleri gerekse duyuşsal özellikleri dikkate alındığında bu dış desteğin önemli olduğu ifade edilebilir. Çünkü ilk defa akademik öğrenme sürecine giren bir çocuk için okulda geçirdiği yaşantıları anlamlandırabilmesi ve okul disiplinine alışabilmesi kolay olmayacaktır. Bu süreçlerin sağlıklı bir şekilde atlatılabilmesi için okul ortamında geçirdiği yaşantıların gerek zihinsel olarak gerek duyuşsal olarak desteklenmesi gerekmektedir. Çocuklar üst kademelere doğru ilerledikçe bu tür durumlara karşı dirençleri artacaktır. Böylelikle eğitimde veli katılımı konusunda yapılan çalışmaların özellikle okul öncesi ve ilkokulda sağılmasının nedeni bu gerekçeler olabilir.

Bir okul öncesi eğitim kurumunda eğitim programının başarıyla uygulanması ve öğrencilerin başarılı olması için aile katılımına ve aile desteğine ihtiyaç vardır. Günümüzde öğretmenler, aile katılımının önemini fark etmiştir. Okul öncesi eğitim programında aile katılımının planlı bir şekilde yapılması gerektiği ve programın vazgeçilmez parçasının aile katılımı olduğu anlaşılmıştır (Çakmak, 2010). Çocuğun ailedeki eğitimine bir kurumda devam ettiği okul öncesi eğitimi, ailelerden soyutlanmış şekilde düzenlenemez. Bilgi vermekten çok beceri ve davranış kazandırmayı amaçlayan okul öncesi eğitim kurumları, çocuğun okul hayatının ilk adımı olduğu için okula karşı yaklaşımını ve tutumunu belirleyecek yer olması bakımından önemlidir ( Yazar ve diğerleri, 2008). Toran ve Özgen'in (2018) okul öncesi eğitimde aile katılımı konusunda yaptıkları çalışmanın sonucunda okul öncesi öğretmenlerin tamamının aile katılımının gerekli olduğu görüşüne inandığı, okuldaki öğrenme ortamının evde de devam etmesi gerektiğini söyleyerek aile katılımı çalışmalarının çocuğun akademik başarısına, problem çözme yeteneğine, dil becerilerine, duygusal gelişimine büyük katkılar sunacağını ifade etmişlerdir. İlköğretim kademesinde aileler veli katılımı konusunda evde üstlerine düşen görevi yaparken yani çocuğun çalışması için iyi bir ortam hazırlayıp ona derslerinde destek olurken okulda veli katılımı konusunda yetersiz kalmışlardır. İlköğretim düzeyinde de sınıf ilerledikçe veli katılımı düşmektedir. Şaban'ın (2011) yaptı̆̆ 1 araştırma sonucunda en çok veli katılımının 1.-3. sınıflarda olduğu, en düşük veli katılımının ise 6.-8. sınıflarda olduğu ortaya çıkmıştır. Şaban (2011), buna gerekçe olarak sınıf ilerledikçe öğrencilerin daha çok sorumluluk sahibi olduğunu ve kendine güveninin arttığını göstermiştir.

Eğitimde veli katılımı konusunda 2000-2018 yılları arasında yapılmış çalışmaların türlerine bakıldığında çoğunluğunu makale oluşturmaktadır. Ardından yüksek lisans tezi ve doktora tezi gelir. Tezler daha zorlu ve uzun zaman gerektiren çalışmalar olduğundan ve velilerle çalışmanın zorlukları da düşünüldüğünde sayının az olması bu gerekçelere dayandırılabilir. Ayrıca ilgili çalışmalarda veri toplama aracı olarak çoğunlukla çeşitli ölçekler kullanılmıştır. Ölçekler içerisinde en çok aile katılım 
ölçeği ve tutum ölçeği uygulanmıştır. Bunun yanında görüşme, anket ve form da kullanılmıştır. Çalışmaların genelinde bir veya iki veri toplama aracı kullanılmıştır.

Eğitimde veli katılımı deyince akla annelerin eğitim sürecine katılımı gelmektir. Oysaki babalar da velidir ve onlar da çocuklarının eğitim-öğretim faaliyetlerinde aktif rol oynamalıdır. Eğitimde baba katılımının azlığının yanı sıra bu konuda yapılmış çalışma da azdır. Eğitimde veli katılımı konusunda ele alınan, incelenen 144 çalışmadan sadece 6'sı baba katılımıyla ilgilidir. Araştırmacıların bu konuya önem verip üzerinde çalışmaları gerekmektedir. Çünkü çocuğun gelişiminde, başarısında anne kadar baba da büyük önem taşır. Toplumun sosyolojik yapısı, ataerkil aile düzeni eğitime baba katılımını engelleyen durumlardir.

Normal gelişim gösteren çocuklarda veli katılımı incelendiği gibi özel gereksinimli çocuklarda da veli katılımı incelenmelidir. Eğitimde veli katılımı konusunda ele alınan, incelenen 144 çalışmadan sadece 5'i özel gereksinimli çocuklarda aile katılımıyla ilgilidir. Araştırmacıların bu konuya önem verip üzerinde çalışmaları gerekmektedir. Çünkü özel gereksinimli çocukların aileleriyle öğretmenleri sürekli iletişim ve iş birliği halinde olmalılar ve gelişmelerden birbirlerini haberdar edip yardımlaşmalılardır. Yıldız (2017) ilkokula devam eden özel gereksinimli çocuğa sahip ailelerin çocuklarının eğitimine katılımlarını incelemiş ve aile katılım düzeylerinin $\% 32.1$ düşük, $\% 38.6$ orta, \%37.2 yüksek olduğunu ortaya koymuştur. Katılım oranının artması öğrencileri olumlu yönde etkileyecektir. $\mathrm{Bu}$ sebepten hem katılımın artması hem de bu konuda yapılan çalışmaların artması gerekmektedir. Aile katılım etkinlikleri ilk olarak özel eğitim kurumlarında başlamıştır. Buna rağmen eğitime veli katılımı konusunda yapılmış çalışmaların özel gereksinime sahip çocuklar üzerinde daha az olması tezat bir durum oluşturmaktadır.

Araştırma kapsamında aşağıdaki öneriler getirilebilir:

- Araştırma sonuçları incelendiğinde, yapılan çalışmaların çoğunluğu anne katılımını temele almaktadır. Babaların eğitim sürecine katılımına yönelik çalışmalar oldukça sınırlıdır. Dolayısıyla eğitimde baba katılımına dair çalışmalara ağırlık verilebilir.

- İncelenen araştırmalarda benzer şekilde özel gereksinimli öğrencilerin ailelerine yönelik veli katılım çalışmaları oldukça sınırlı sayıdadır. Dolayısıyla bu tür öğrencilerin velilerine yönelik çalı̧̧malar yapılabilir.

- İncelenen araştırmaların büyük çoğunluğunun büyükşehirlerde gerçekleştirildiği sonucuna ulaşılmıştır. Bu bağlamda büyükşehirlerin dişında diğer illerde -özellikle Güneydoğu ve Doğu Anadolu illerinde- çalışmalar yapılabilir.

\section{Kaynakça}

Akkabak Yıldız, T. (2018). 5-6 yaş grubu için geliştirilen aile katılımlı farklılıklara saygı programının çocukların farkllllklara saygı düzeyine etkisinin incelenmesi, Yayınlanmamış yüksek lisans tezi, Marmara Üniversitesi, Eğitim Bilimleri Enstitüsü.

Albez, C. (2016). Okul yöneticilerinin veli katılım çalışmalarını örgütleme becerilerinin incelenmesi, Yayınlanmamış doktora tezi, Atatürk Üniversitesi, Eğitim Bilimleri Enstitüsü.

Albez, C., \& Ada, Ş. (2017). Okul-aile ortaklı̆̆ı: güçlükler, beklentiler, gereksinimler, öneriler. Anadolu Ĕ̈itim Liderliği ve Öğretim Dergisi, 5(2), 1-18.

Binicioğlu, G. (2010). İlkögrretimde okul-aile iletişim etkinlikleri: ögretmen ve veli görüşleri, Yayınlanmamış yüksek lisans tezi, Anadolu Üniversitesi, Eğitim Bilimleri Enstitüsü.

Can, B. (2009). İlköğretim programının uygulanması sürecine velilerin katılımları ve okula ilişkin tutumları, Yayınlanmamış yüksek lisans tezi, Eskişehir Osmangazi Üniversitesi, Sosyal Bilimler Enstitüsü.

Canpolat, T. (2011). Öğretmen aile iş birliği ile ailelerin ĕgitim ihtiyaçlarının belirlenmesi, Yayınlanmamış yüksek lisans tezi, Marmara Üniversitesi Fen Bilimleri Enstitüsü.

Cömert, D., \& Güleç, H. (2004). Okul öncesi eğitim kurumlarında aile katılımının önemi: öğretmen, aile, çocuk ve kurum. Sosyal Bilimler Dergisi, 6(1), 132-145.

Çamlıbel Çakmak, Ö. (2010). Okul öncesi eğitim kurumlarında aile katılımı. Abant İzzet Baysal Üniversitesi Sosyal Bilimler Enstitüsü Dergisi, 1(20), 1-17.

Çalışkan, N., \& Ayık, A. (2015). Okul aile birliği ve velilerle iletişim. Ahi Evran Üniversitesi Sosyal Bilimler Enstitüsü Dergisi, 1(2), 69-82. 
Göktaş, İ. (2015). Aile katılımı ve sosyal beceri eğitimi programlarının tek başına ve birlikte 4-5 yaş çocuklarının sosyal becerileri ve anne-çocuk ilişkileri üzerindeki etkisinin incelenmesi, Yayınlanmamış yüksek lisans tezi, Pamukkale Üniversitesi, Eğitim Bilimleri Enstitüsü.

Gül, E. (2007). Eğitimde çocuk başarısı için okul-aile iş birliği, Yayınlanmamış yüksek lisans tezi, Yeditepe Üniversitesi Sosyal Bilimler Enstitüsü.

Gülcan, M., \& Taner, N. (2011). Öğretmen görüşlerine göre ilköğretimde ev ziyaretinin okul başarısına etkisi (Kahramanmaraş il örneği). Mehmet Akif Ersoy Üniversitesi Eğitim Fakültesi Dergisi, 11(22), 129-144.

Keçeli Kaysılı, B. (2008). Akademik başarının arttırılmasında aile katılımı. Ankara Üniversitesi Ĕgitim Bilimleri Fakültesi Özel Ë̆itim Dergisi, 9 (1) 69-83.

Kuzıltaş, E. (2009). Okul öncesi eğitimde uygulanan aile katılım çalışmalarının 5-6 yaş grubu çocukların dil becerilerinin gelişimine etkisi. Yüksel Lisans Tezi, Atatürk Üniversitesi, Sosyal Bilimler Enstitüsü.

Köyceğiz, M., Ağaçdan, M., Akaydın, D., Yorgun, E., \& Tezel Şahin, F. (2016). Milli eğitim bakanlığı okul öncesi eğitim programlarında aile katılımının dünü ve bugünü. Uluslararası Sosyal Araştırmalar Dergisi, 9(45), 619-625.

Oktay, A., Gürkan, T., Zembat, R., P., \& Unutkan, Ö. (2003). Okul öncesi programı uygulama rehberi Ne yapıyorum? Neden yapıyorum? Nastl yapmalıyım? İstanbul: Ya-Pa Yayınc1lık.

Ömeroğlu, E., \& Yaşar, M. (2005). Okul öncesi eğitim kurumlarında ailenin eğitime katılımı. Bilim ve Aklın Aydınlı̆̆ında Ë̆itim Dergisi, 62.

Özdinç, T. (2014). Okul öncesi eğitimde aile katılımında sosyal medya kullanımı: bir durum çalışması, (Yayınlanmamış yüksek lisans tezi), Bahçeşehir Üniversitesi, Eğitim Bilimleri Enstitüsü.

Şaban, C. (2011). Illkögretim okullarında velilerin eğitime katılım düzeyleri ve tercih ettikleri katılım türleri, Yayınlanmamış yüksek lisans tezi, Yeditepe Üniversitesi, Sosyal Bilimler Enstitüsü.

Şahin, T.F., \& Ünver, N. (2005). Okul öncesi eğitim programlarında aile katılımı, Kastamonu Ĕgitim Dergisi, 13(1), 23-30.

Toran, M., \& Özgen, Z. (2018). Eğitimde nitel araştırmalar okul öncesi eğitimde aile katılımı: öğretmenler ne düşünüyor, ne yapıyor?. Eğitimde Nitel Araştırmalar Dergisi, 6(3), 229-245.

Yazar, A. , Çelik M. , Kök M. (2008). Aile Katılımının Okul Öncesi Eğitimde ve 2006 Okul Öncesi Eğitim Programındaki Yeri. Atatürk Üniversitesi Sosyal Bilimler Enstitüsü Dergisi, 12(2).

Yıldırım, M. (2012). Kuruma dayalı aile eğitim programlarının ilköğretim 5. Sinıf ögrrencilerinin okul başarılarına etkileri, Yayınlanmamış yüksek lisans tezi, Niğde Üniversitesi Eğitim Bilimleri Enstitüsü.

Yıldırım, A., \& Şimşek, H. (2016). Nitel araştırma yöntemleri, Ankara: Seçkin Yayıncılık.

Yıldız, H. (2017). Illkokula devam eden özel gereksinimli çocuğa sahip ailelerin çocuklarının eğitimlerine katılımlarının incelenmesi. Türkiye Eğitim Dergisi, 2(2), 82-94. 